Protestantismo em Revista é licenciada sob uma Licença Creative Commons.

http://dx.doi.org/10.22351/nepp.v45i1.3142

\title{
UMA ANÁLISE BÍBLICA DA QUESTÃO DO DÍZIMO E A SUA APROPRIAÇÃO PELAS IGREJAS NEOPENTECOSTAIS
}

\author{
A biblical analysis of the question of tithing and its appropriation by the neo-pentecostal \\ churches
}

Fabiano Veliq *

\begin{abstract}
Resumo:
O presente artigo tem como intuito evidenciar um trajeto bíblico sobre a questão dos dízimos mostrando a construção histórica desse conceito e também mostrar a sua apropriação nas igrejas evangélicas neopentecostais. O dízimo no texto bíblico tem um caráter fortemente social, mas esse princípio tem sido deixado de lado nas igrejas neopentecostais onde o caráter meramente financeiro é enfatizado várias vezes esquecendo a dimensão social do dízimo.
\end{abstract}

Palavras-chave: Dízimo. Neopentecostais. Bíblia. Igreja.

\begin{abstract}
:
The purpose of this article is to show a biblical trajectory on the question of tithes showing the historical construction of this concept and also to show its appropriation in the neo-Pentecostal evangelical churches. Tithing in the biblical text has a strongly social character, but this principle has been overlooked in neo-Pentecostal churches where the merely financial character is emphasized several times by neglecting the social dimension of tithing.

Keywords: Tithing. Neopentecostals. Bible. Church.
\end{abstract}

\section{Introdução}

A questão do dízimo é um assunto muito falado e pouco estudado dentro das igrejas evangélicas, e fonte de muitos embates entre os que defendem uma postura conservadora, ou seja, no sentido em que o dízimo deve ser dado na igreja e outros que afirmam que os dízimos se aplicam apenas aos judeus e por isso não deve ser exigido para os gentios.

O interesse do presente texto é elucidar o propósito do dízimo desde a sua instituição pela lei, passando pelas conotações adquiridas pelo dízimo até os dias atuais.

[Texto recebido em outubro de 2017 e aceito em agosto de 2018, com base na avaliação cega por pares realizada por pareceristas ad hoc]

* Doutor. Atualmente realizando estágio pós-doutoral na FAJE em Belo Horizonte, MG. E-mail: veliqs@gmail.com 
O presente texto não terá a pretensão de esgotar o assunto e nem terá um caráter exegético, mas sim um caráter hermenêutico, tendo em vista a exposição da questão dos dízimos.

\section{Um trajeto bíblico}

A primeira citação que temos a respeito do dízimo se encontra em Gênesis14:201 onde Abraão dá o dízimo a Melquisedeque depois de ter derrotado os reis que haviam sequestrado seu sobrinho Ló. "E bendito seja o Deus altíssimo, que entregou seus inimigos em suas mãos e Abraão lhe deu o dízimo de tudo" (Gn 14:20).

A figura de Melquisedeque é emblemática no Antigo Testamento (AT) uma vez que ele é tido como "sem pai sem mãe, sem genealogia, sem princípio de dias, nem fim de vida, feito semelhante ao filho de Deus" (Hebreus 7:3). Fritz (2000) e Dattler (1980) acreditam se tratar de uma teofania, uma vez que ele aceitou o dízimo de Abraão, no entanto as pesquisas mais recentes como Champlim (2001) e Davis (1996) não encaram Melquisedeque dotado de um ser sobrenatural, mas apenas um rei conhecido da época de Abraão. O que é relevante para o presente texto é que Abraão deu o dízimo a Melquisedeque em forma de agradecimento pela vitória alcançada. Tem-se então a primeira forma que o dízimo foi usado: exprimir agradecimento por uma vitória.

O dízimo depois reaparece em Gn 28:20 na figura de Jacó que promete a Deus o dízimo se Deus lhe garantisse um bom êxito em sua empreitada.

\footnotetext{
“Então Jacó fez um voto, dizendo: Se Deus estiver comigo, cuidar de mim nesta viagem que estou fazendo, prover-me de comida e roupa, e levar-me de volta em segurança à casa de meu pai, então o Senhor será o meu Deus. E esta pedra que hoje coloquei como coluna servirá de santuário de Deus; e de tudo o que me deres certamente te darei o dízimo" (Gn 28:20-22).
}

Interessante notar que estas duas primeiras citações do dízimo se encontram antes do estabelecimento da lei mosaica. Tanto Abraão quanto Jacó se encontravam cronologicamente antes da instituição da lei e, no entanto, já dizimavam e prometiam dízimo como forma de agradecimento. Quando a lei é instituída por Deus através de Moisés, Deus deixa claro qual seria a prática a ser adotada em relação aos dízimos. Em Levítico 27:30, Deus afirma “Todos os dízimos da terra, seja dos cereais, seja das frutas, pertencem ao Senhor, são consagrados ao Senhor."

Em Nm 18:21, 24, 26 e 28, o dízimo foi entregue aos levitas em retribuição ao trabalho que eles exerciam na Tenda do Encontro. A partir desse momento se institui que apenas os levitas poderiam se achegar à Tenda do Encontro e foi vetado a qualquer outro o fazê-lo. Os levitas não receberiam herança sobre a divisão das terras. A herança deles seria o Senhor e, em lugar da terra, o Senhor concedia aos levitas os dízimos que os israelitas

1 Para todas as referências bíblicas será adotada a versão NVI- Editora Vida 2000. 
apresentassem à Ele (Nm18:24). No entanto, os levitas também deveriam dar o dízimo dos dízimos ao sacerdote, ou seja, a melhor parte dos dízimos deveria ser dada ao sacerdote. Os levitas poderiam comer esta parte e ela seria considerada como o salário pelo trabalho executado na Tenda do Encontro.

Percebe-se aqui que Deus dá o dízimo que antes pertencia apenas a Ele como relata em Lv 27:30 aos levitas, uma vez que estes não tem parte na terra. Deus, ao fazer isso, fica com apenas o dízimo de todos os dízimos que era dado pelos israelitas. Esta entrega de $90 \%$ da receita para os levitas têm uma função social. Primeiramente que ela era o pagamento pelo trabalho exercido pelos levitas no templo. Em segundo lugar, Deus, ao passar o dízimo aos levitas, tem outro intento que ficará evidenciado no texto de Deuteronômio.

Em Deuteronômio ${ }^{2}$, Deus novamente dá outras instruções em relação ao dízimo. Em Deuteronômio 12 Deus instituiu o local correto onde o dízimo deveria ser dado. Ao chegar neste lugar, o povo deveria se alegrar perante o Senhor e comer tudo o que tivessem levado para o sacrifício e para o dízimo. Todos poderiam comer fartamente, até mesmo os impuros poderiam comer aquilo que seria entregue ao Senhor no local que Ele determinasse. Deus deu instruções para que o povo se alegrasse, mas sem se esquecer dos levitas que habitavam com eles, uma vez que estes não tinham parte na terra. A única restrição era o sangue, que não deveria ser comido por ser vida (Dt 12:23). A entrega do dízimo foi seguida do sentimento de alegria. A ocasião era ocasião para festa, e Deus queria que isso fosse feito por quem estivesse ali, era um momento de regozijo e não de constrangimento.

Em Dt 14; 24-29, Deus novamente manda que o povo coma o dízimo na presença do Senhor no local que Ele escolheu para tal.

No entanto, se o local for longe demais e vocês tiverem sido abençoados pelo Senhor,
o seu Deus, e não puderem carregar o dízimo [...] troquem o dízimo por prata, e
levem a prata ao local que o Senhor, o seu Deus tiver escolhido. Com a prata
comprem o que quiserem: bois, ovelhas, vinho ou outra bebida fermentada, ou
qualquer outra coisa que desejarem. Então juntamente com suas famílias, comam e
alegrem-se ali, na presença do Senhor, o seu Deus. E nunca se esqueçam dos levitas
que vivem em suas cidades, pois eles não possuem propriedade nem herança
própria. Ao final de três anos, tragam todos os dízimos da colheita do terceiro ano,
armazenando-os em sua própria cidade para que os levitas, que não possuem
propriedade nem herança, e os estrangeiros, os órfãos e as viúvas que vivem na sua
cidade venham comer e saciar-se, e para que, o Senhor o seu Deus, os abençoe em
todo o trabalho de suas mãos. (Dt 14,24-29)

Nota-se aqui Deus instituindo o dízimo como partilha para proporcionar uma espécie de igualação social entre todos os participantes da comunidade. Deus está

2 Interessante notar juntamente com SULCA e ARIZA (2016 p. 251) que "o texto do Deuteronômio está dirigido ao povo, não a um setor dele, mas a todo ele: o ambiente em que se desenvolve é aquele em que transita essa comunidade." SULCA, José L. Verdi, ARIZA, Newell Abiud Fonseca. Uma lei, duas tradições e muitos interesses. O código Deuteronômico e o projeto Sadoquista legislam sobre o dízimo. In CARNEIRO, Marcelo da Silva, OTTERMANN, Monika, FIGUEIREDO, Telmo José de Amaral (Org.) Pentateuco. Da formação à recepção: Contribuições ao VII Congresso ABIB - UMESP. São Paulo. Paulinas. 2016. 
preocupado com a alegria do povo, como também em saciar o órfão, a viúva e o estrangeiro. Percebe-se que tanto em Dt 12 como em Dt 14, o dízimo foi comido pelo povo que celebrou as bênçãos de Deus. No primeiro texto (Dt 12), todos podem comer do produto do dízimo e se alegrar perante o Senhor sem se esquecerem dos levitas que habitavam entre eles. No segundo texto (Dt 14), os órfãos, os estrangeiros e as viúvas também deveriam ser lembrados. O dízimo da colheita do terceiro ano era para que os levitas, os órfãos, as viúvas, e os estrangeiros pudessem comer e se saciar. No terceiro ano, os que não tinham parte na terra poderiam comer e se saciar. No entanto, pode-se notar que esta admoestação é um reforço à festa que era feita na entrega do dízimo, onde, tanto puros, quanto impuros, podiam comer e se alegrar na presença do Senhor.

A questão do dízimo é que agora ele não é mais somente dos levitas, mas pertence a todos os que "não têm parte na terra", e aos órfãos, aos estrangeiros, as viúvas, e aos levitas. Da mesma forma o texto de Deuteronômio 26,1-11 relata um verdadeiro ritual feito em família. As famílias reconhecem a promessa cumprida e fazem oferta dos primeiros frutos da terra recitando a grande confissão de fé que reconhece Javé como seu único Deus que age na história do povo.

O dízimo adquire no Deuteronômio um aspecto fortemente social, visando uma igualdade entre o povo. Ao festejar com o dízimo o povo de Israel deveria ter em mente todos os que não tinham parte na terra. O dízimo que antes pertencia somente ao Senhor (Lv 27:30) passou aos levitas (Nm 18: 21-28) e em seguida passa para todos os que não têm parte na terra (Dt 14: 22-28). Todo esse movimento em torno do dízimo mostra que a preocupação central da noção do dízimo era que o povo se lembrasse de Deus, que o povo tivesse alegria e que a sociedade pudesse ter igualdade social.

A preocupação central do dízimo não estava era com o dinheiro que o povo daria, mesmo porque, a maioria do dízimo era dada em forma de bens, colheitas etc. Ele estava preocupado com "saúde" do povo. O Deus de Israel queria que o povo visse Nele a fonte de todo provimento e visse que esse provimento deveria ser igual a todos os membros da comunidade. Daí o dízimo deixa de ser apenas objeto de agradecimento como nas histórias de Abraão e Jacó e passa a ter uma conotação altamente social.

Esta evolução da noção e função do dízimo pode ser vista no decorrer das passagens que foram analisadas acima. $\mathrm{O}$ que foi visto até agora é que o dízimo sofreu várias novas aplicações com o passar das gerações bíblicas. O final da lei sobre o dízimo recai na alegria, na memória de Deus, e no bem-estar social do povo. No entanto, os princípios do dízimo se perderam com o passar do tempo.

O povo de Israel se voltou para a atitude exterior do dízimo e esqueceu de seus princípios. Deus, várias vezes, afirma que Ele não mais aceitaria os holocaustos as ofertas e os dízimos que o povo estava dando, porque eles simplesmente estavam preocupados com a forma exterior e não com os princípios. Em Miquéias 6:6,7 pode-se ver que a questão 
exterior não é aquela que Deus quer, mas sim que o povo se voltasse para agir retamente para com Deus.

Outra vez em Isaías 1:11-17, Deus novamente admoesta o povo para que não apenas trouxessem os sacrifícios e ofertas, mas que se limpassem e defendessem a causa dos órfãos e das viúvas. A mesma admoestação foi dada por Jesus aos fariseus em Mateus 23: 23, quando Jesus afirmou que os fariseus davam o dízimo da hortelã e das hortaliças e ignoravam o mais importante da lei que é a justiça, a misericórdia e a fidelidade. O povo passou então a dar mais ênfase para a forma externa do que para os princípios.

O que não se pode esquecer é que paira sobre o povo de Israel a doutrina da retribuição como descrita muito bem no livro de Jó. Segundo esta doutrina, Deus recompensa os bons e pune os maus. Portanto, a noção do dar o dízimo, enquanto obra, está muito presente na cabeça do israelita que assim o faz para que as bênçãos do Senhor o alcance. No entanto, como visto, o exterior para Deus é o que menos importa, e sim a intenção do coração. No entanto, o exterior é o que é enfocado pelo povo.

Jesus traz de volta a questão do dízimo para o âmbito do coração ao falar aos fariseus sobre suas práticas que ignoravam os princípios da lei. Pode-se notar, na exposição feita até agora, que Deus deixa bem claro qual o seu intuito em estabelecer a lei do dízimo. No entanto, o que se vê nos dias de hoje é um abandono dos princípios e uma acentuação no âmbito do externo. Para justificar esta posição, passamos agora à análise do texto de Malaquias 3:8-10 que são os versículos mais usados para justificar a cobrança dos dízimos dentro das igrejas evangélicas atualmente.

\section{Os Versículos de Malaquias 3:8-12}

Os versículos que serão trabalhados são os mais usados nas igrejas evangélicas na hora do dízimo e das ofertas. O tom das palavras de Malaquias são bem rudes e incisivas no tocante as questões dos dízimos e das ofertas. No entanto, é preciso compreender o uso desse tom por parte do profeta

O livro de Malaquias é situado na época de Neemias e da reconstrução do templo pelos israelitas ${ }^{3}$.

As palavras de Malaquias começam no versículo 8, chamando aos israelitas de ladrões porque estavam roubando a Deus nos dízimos e nas ofertas e por isso estavam sobre grande maldição. O profeta então conclama a todos para trazerem todos os dízimos à casa do Senhor para que houvesse mantimento (grifo meu) na casa de Deus e incita o povo a fazer prova de Deus e Ele os abençoaria, impediria que as pragas chegassem até o povo e as nações os considerariam felizes.

Pode-se notar que todo o livro de Malaquias é de uma entonação mais veemente. Esta entoação se deve ao fato da geral mudança pela qual passa o povo de Israel e pela total

3 Bíblia de referência Thompson - Editora Vida 1999. 
falta de referência que o povo estava passando neste momento de sua história. O povo acaba de voltar do exílio e começa a reconstruir uma cidade completamente destruída. A maioria dos referenciais de Israel tinha se perdido ao saírem de sua terra. Outros valores foram adquiridos por eles, outra cultura novamente os influenciou. Os pilares, estão frouxos, a referência, é, portanto, necessária.

E para se estabelecer os pilares é preciso que as bases estejam bem firmes, e para isso, as regras precisam ser claras, não podem deixar dúvidas. Em Malaquias 2:16, Deus afirma pela boca do profeta "Eu odeio o divórcio". Se consultarmos a lei mosaica vê-se que o divórcio era permitido na lei. Em nenhuma parte da lei, a questão do divórcio é colocada de forma tão incisiva quanto o é em Malaquias. Esta necessidade de definir as coisas, portanto se insere num contexto de uma mudança radical e, portanto significativa do povo de Israel.

Ao falar da questão do dízimo o que Malaquias deixa bem claro é que todos os dízimos deveriam ser trazidos a casa do Senhor (Vê-se que aqui já existe a figura do templo envolvida como um lugar ao qual devem ser trazidos os dízimos. Este deveria ser entregue no local determinado por Deus, que poderia variar, uma vez que o povo estava no deserto indo para a Terra Prometida. Embora o templo já estivesse construído, a instrução do Senhor foi dada para o povo levar o dízimo ao local que Deus o determinasse), para que houvesse mantimento na casa de Deus.

Os dízimos em Malaquias visavam o mantimento no templo, que mais uma vez recai na figura daqueles que não têm parte na terra. A figura do templo é de extrema importância para entender em que o povo estava roubando a Deus. Não trazendo os dízimos e as ofertas, aqueles que dependiam do templo estavam sendo roubados da parte que cabia a eles. A admoestação de Jesus cabe aqui “O que vocês deixaram de fazer a um destes pequeninos a mim deixaram de fazê-lo" (Mt 25:45), neste sentido, o povo estava roubando de Deus, uma vez que privavam os que não tinham parte na terra de receber aquilo que Deus tinha instituído que seria a parte deles.

Assim, ao roubar o pequenino o homem roubava de Deus. Não trazendo o dízimo à casa de Deus, aqueles que deles dependiam passavam necessidade. O que está em jogo em Malaquias é o princípio da igualdade social. Isso fica bem claro quando o profeta afirma que o dízimo deveria ser trazido para que houvesse mantimento. É a figura da pessoa que está em jogo no texto de Malaquias não é a instituição "templo". O mantimento é para aqueles que não têm parte na terra. O órfão, a viúva, o levita e o estrangeiro precisavam desse mantimento e estavam sendo roubados pelo povo.

Deus promete uma recompensa (uma vez que a doutrina da retribuição é a teologia vigente, o profeta não pode falar além daquilo que ele mesmo experimenta) para aqueles que trouxessem o dízimo. Deus impediria que as pragas chegassem às suas colheitas e as videiras nos campos, não perderiam os frutos, e as nações os chamariam felizes porque a terra seria maravilhosa. Por que a terra seria maravilhosa? Porque a justiça estaria sendo 
revelada a partir da obediência ao princípio da igualdade social através do dízimo. Analisando os versículos de Malaquias, nota-se que a questão implícita novamente recai sobre àqueles que não têm parte na terra. Só quando as rendas fossem justamente distribuídas é que as nações os reconheceriam como felizes.

\section{Uma conceituação sobre o dízimo}

O dízimo significa a décima parte e vimos acima que no contexto bíblico essa décima parte envolvia não apenas a questão financeira, mas aquilo que o sujeito produzia na terra, no campo, etc. Os dízimos na igreja passaram por todo um processo histórico de transformação, o que nos faz repensar a sua aplicabilidade nos dias de hoje. Segundo Elia "a palavra "dízimo" deve ser entendida dentro de um contexto e sentido novos"4. Hoje quando se fala em dízimo, antes da contribuição em dinheiro, entende-se a participação do cristão na comunidade de forma ativa e não de forma legalista. No entanto, o que vemos nas igrejas evangélicas, principalmente de vertente mais neopentecostal é que o versículo de Malaquias, na maioria das vezes, é usado de forma errada, colocando de tal forma que o não trazer o dízimo é abrir uma porta para que a maldição chegue a casa deste que não o dá. O que se faz é colocar um julgo enorme sobre a vida daquele que não dizima, fazendo com que este o faça por medo e não por princípio.

Gasques coloca de forma bastante clara que

Dízimo e dinheiro são como que excludentes! Para se transformar em dinheiro, o dízimo necessita passar por um filtro de altíssima temperatura e, depois, na linha final se tornar um volume econômico. Inverter esse processo é o pior caminho 5 .

Dessa forma o que rege o princípio do dízimo na igreja é a noção de partilha e por isso que tal prática pressupõe um amadurecimento por parte do cristão. $\mathrm{O}$ que vemos acontecer em várias igrejas evangélicas, sob o nome de uma falsa obediência ao "princípio do dízimo" é colocar sobre o membro um fardo de contribuir por medo para a instituição religiosa a qual o indivíduo pertence. O erro está em se atribuir a Deus a necessidade do dinheiro, uma vez que a necessidade é humana.

A instituição religiosa realmente precisa de dinheiro para pagar contas, funcionários e outros gastos que se fazem necessários, no entanto, o "clamor" pelo dízimo deveria ser feito evidenciando o real motivo do dízimo, e não criando um misticismo onde Deus é aquele que precisa do dinheiro, e quem não der será punido com "devoradores, migradores, cortadores e destruidores", é aí que se encontra um erro grave ao se falar em dízimo atualmente.

4 ELIA, Marta Sampaio Lima. Oferecei o Dízimo segundo o costume. São Paulo: Edições Loyola, 1987 p. 15

5 GASQUES, Pe Jerônimo. Manual essencial do dízimo. Instrumento, ferramenta e orientação para iniciação, compreensão e prática do dízimo na paróquia. São Paulo: Edições Loyola. 2017. p. 21. 
Esse erro é de ordem prática, mas há outro erro que pode ser dito "bíblico" que é a total negligência do concílio de Jerusalém descrito em Atos 15, onde ficaram definidas quais as diretrizes deveriam ser passadas aos gentios. Dentre estas recomendações o dízimo não figura. Dentro da nova lei da nova aliança foi ordenado aos cristãos para dispensarem aos ministros da Igreja uma honesta sustentação "pois digno é o trabalhador do seu salário" (Mt 10,10).

Segundo aponta Gasques “nos primeiros tempos do cristianismo, viviam os clérigos das ofertas espontâneas dos fiéis e a questão do dízimo não eram pagos. [...] O mesmo se pode ver em Orígenes. Dos três primeiros séculos não há um documento sequer que fale do dízimo." ${ }^{6}$ Segundo o mesmo autor apenas no Concílio Turonenese, em 567, foi publicada uma carta em que se aconselhava os fiéis a pagar o dízimo e em 585 que o costume antigo de pagar os dízimos teria se reestabelecido. Já a lei eclesiástica sobre o dízimo foi dada apenas no II Concílio Macaense entre os anos de 581 e 587 e lá se punia com excomunhão aqueles que não pagassem os dízimos já aconselhados no concílio de Tours. No ano de 650 o cânon do terceiro Concílio de Ruão ameaçou de excomunhão a quem, depois de tríplice admoestação, não pagasse o dízimo dos frutos, bois, ovelhas, etc.

Percebe-se que mesmo não figurando como ordenação no novo testamento de forma explícita, e nem não se encontrando entre as recomendações feitas pelos apóstolos aos gentios, o dízimo se incorporou à história da igreja a partir do século 4.

\section{Os neopentecostais e o dízimo}

Uma das características principais das igrejas neopentecostais é a sua vinculação à conhecida "teologia da prosperidade". Dentro dessa teologia, a questão do dízimo aparece de forma muito forte e pode ser vista de forma nítida nos apelos feitos aos fiéis para que eles contribuam com o templo. Dentro da igreja evangélica de vertente neopentecostal fica evidenciado na prática de alguns líderes em relação ao dízimo, que o que é feito é um "selfservice de leis" sem nenhum tipo de vinculação à tradição da igreja, uma vez que a igreja evangélica não tem na tradição uma base para as regras de fé. Neste contexto as leis do Antigo Testamento são usadas a partir da conveniência e a lei referente ao dízimo ganha especial importância, pois é aquela capaz de coagir o membro a contribuir com a instituição.

Essa relação do dízimo como lei que deve ser mantida em detrimento de outras, apenas evidencia essa prática que visa à conveniência. Como a igreja não pode abrir mão da renda, ela coloca sobre o membro a responsabilidade de mantê-la e o faz colocando sobre ele um fardo e uma promessa de punição se não fizer a sua parte. Por medo da punição muitos dizimam, no entanto, eles estão novamente se atendo à forma da contribuição e esquecendo-se do princípio assim como os israelitas criticados por Jesus faziam.

6 GASQUES, Pe. Jerônimo. O dízimo no terceiro milênio. Visão Ecumênica. São Paulo: Edições Loyola. 1997 p. 15. 
No entanto, essa prática é muito interessante para a instituição que com isso se mantêm a custa de um sofrimento psicológico do membro que está, portanto, sempre com medo de que algo aconteça a ele. O dízimo como já foi dito no início visa muito mais que a forma, visa o coração do homem, visa a mente do homem, uma vez que é uma forma dele se lembrar de Deus que lhe concedeu todas as coisas, visa o psicológico do homem uma vez que deve ser motivo de alegria o fato de ver que Deus tem suprido as necessidades e visa o social do homem, uma vez que o dízimo se destina a todos aqueles que não têm parte na terra.

Com a institucionalização da fé, o que aconteceu foi que esses princípios foram esquecidos e a forma foi exaltada. O exterior é que importa, e não mais o interior. Isso em termos bíblicos é totalmente vazio, uma vez que Deus olha o coração do homem e não apenas o que os seus atos dizem. Dentro das igrejas neopentecostais é comum os líderes afirmarem durante suas orações que não se trata de uma negociação, mas que apenas estão requerendo o que diz a palavra de Deus no tocante aos dízimos e ofertas.

No final, o que se vê é uma relação onde o fiel dá o dízimo e em troca, quer receber as bênçãos de Deus. Neste contexto, aquele que não contribui é visto como quem está "roubando de Deus", ao passo que, como foi dito, o Deus roubado não é o Deus metafísico, mas o Deus que se revela nos que não têm parte na terra. Esta acusação feita pelos líderes neopentecostais é imoral e antibíblica. Como Paulo afirma em Romanos, "nenhuma condenação há para os que estão em Cristo Jesus." (Rm 8:1) Tendo em vista isto, pode-se ver que o aspecto coercitivo do dízimo está longe de promover uma obediência por parte do fiel, mas provoca um medo de que "o Deus retribuidor" venha a lhe punir com "pragas e gafanhotos".

Esta apropriação do gafanhoto como um demônio que ataca quem não dizima é uma apropriação indevida no tocante a uma hermenêutica e a uma exegese bíblica. A figura do gafanhoto exposta no texto é mais bem entendida se tomada em seu sentido literal, uma vez que a cultura agrícola era predominante na época da reconstrução do muro. Não há, portanto nenhuma alusão no texto de Malaquias ao gafanhoto sendo entendido como um demônio, ou uma entidade, ou algo que atacará àquele que não dizimar.

O dízimo, portanto, em vez de servir como agente modificador da sociedade por meio do dom da partilha está servindo (em várias igrejas evangélicas) como aspecto coercitivo para que o fiel contribua com uma instituição. A institucionalização do dízimo retira deste o seu caráter social e o coloca como um imposto. Mas não simplesmente um imposto, mas um imposto que é colocado por Deus sob a condição de amaldiçoar quem não o pagar. Esta perda do sentido do dízimo pode ser vista todo domingo na maioria das igrejas evangélicas. Não nego o fato de que a instituição tem despesas, funcionários a pagar, coisas que precisam ser consertadas e outros tipos de serviço que qualquer "empresa" possui e o dinheiro é o que fará com que estas necessidades sejam sanadas. Não há aqui uma crítica à contribuição por parte do fiel. O que deve ser questionado são as motivações que o levam a contribuir. 
O que se vê, é que a maioria dos fiéis contribui por medo de serem castigados por Deus, e é isso que deveria ser mudado dentro da igreja evangélica. As necessidades físicas da igreja são visíveis e é papel do membro que a frequenta contribuir para que elas sejam sanadas. O erro está em atribuir a Deus uma necessidade que é institucional. A contribuição, portanto é necessária. Mas em vez de coagir o povo a dizimar, o que deveria ser feito é ensinar o povo a ofertar, a usar da liberdade e da liberalidade para promover as melhorias na instituição. Não se deve atribuir a Deus uma cobrança que é meramente institucional.

Por que então nas igrejas neopentecostais se dá ao dízimo um estatuto para além da lei, e em relação a outras leis elas só servem para os judeus? A resposta a que se chega é a questão da conveniência. O que é conveniente para a instituição é preservado sobre o pretexto de ser a vontade de Deus que tal coisa seja como é e as outras são abandonadas sob o pretexto de serem específicas para um povo específico, a saber, os judeus.

Essa diferenciação, no entanto carece de explicação não podendo ser pautada meramente na conveniência. Como esta explicação não encontra uma base sólida, ela se apoia na convicção de quem detém o poder na instituição. O líder da instituição (neste caso, o pastor) é quem irá definir o que vale ser tomado como lei e o que não vale. Mediante o seu entendimento da bíblia, uma lei do AT poderá ser aceita ou não na igreja.

Como o despreparo por parte dos pastores em várias igrejas é grande, o que se vê são inúmeras igrejas com doutrinas e hábitos muito questionáveis. A questão do dízimo é apenas uma das questões que precisam ser revistas dentro das igrejas evangélicas. Isso implica em uma hermenêutica voltada para o esclarecimento da questão, bem como de um maior preparo por parte dos líderes das igrejas para promoverem esse esclarecimento.

Como essa revisão geraria um maior esclarecimento da comunidade onde a ideologia dominante a massacra em nome de Deus, isso não é incitado pelos próprios líderes que se verão perdendo o seu poder de dominação quando o povo começar a pensar. É interessante ressaltar como Cristo fazia com seus discípulos incitando-os a pensar sobre a lei, a pensar o papel individual deles no projeto divino e a refletir sobre o que significava tudo aquilo que estava sendo falado. Ao perguntar para eles: "E vocês, o que dizem que eu sou?" Jesus está incitando-os a pensar, a refletir no real motivo do porquê eles estão fazendo aquilo que estão fazendo.

\section{Considerações Finais}

Jesus sabia da importância de se refletir sobre as ações, bem como o que uma mente esclarecida seria capaz de fazer pela comunidade. A fé sem reflexão é fanatismo, a fé meramente imposta não modifica a sociedade, não modifica a comunidade onde o membro se encontra. Pensar a fé é pensar a prática cristã, é pensar as minhas atitudes dentro da igreja e tentar entender o porquê ajo como ajo. Essa prática deve atingir todos os setores da igreja; desde o líder de onde vêm as diretrizes até o membro que às vezes simplesmente obedece sem mesmo questionar o líder sobre o real sentido da ordem ou da prática. 
A igreja evangélica precisa repensar suas práticas e carece de mudanças urgentes. A meu ver, isso só acontecerá quando nos voltarmos para a Bíblia e a interpretarmos de uma maneira coerente com os princípios ensinados por Jesus; não mais pautando nossas ações em conveniências, ou em práticas irrefletidas. Segundo afirma Gasques (1997 p. 23)

Ele (o dízimo) nos educa para a justiça, que se torna concreta na partilha. [...] Ir ao dízimo exige uma atitude de amadurecimento da fé e da partilha. Podemos observar quantos são dizimistas, mas o são de forma desleixada e incômoda. O dízimo nos ensina a formar uma nova sociedade, na qual todos tenham acesso aos bens da vida.

\section{Referências}

BÍBLIA SAGRADA. Tradução NVI. Editora Vida 2000

BÍBLIA DE REFERÊNCIA THOMPSON. Tradução de João Ferreira de Almeida. Editora Vida. 1999

CHAMPLIN, R. N; BENTES, J.M. Enciclopédia de Bíblia, Teologia e Filosofia. v.4. São Paulo: Hagnos, 2001.

DATTLER, Frederico. A Carta aos Hebreus. São Paulo: Paulinas, 1980.

DAVIS, John D. Dicionário da Bíblia. 19 ed. Rio de Janeiro: JUERP, 1996.

ELIA, Marta Sampaio Lima. Oferecei o Dízimo segundo o costume. São Paulo: Edições Loyola, 1987.

FRITZ, Laubach. Carta aos Hebreus: comentário esperança. Tradução de Werner Fuchs. Curitiba: Esperança, 2000.

GASQUES, Pe Jerônimo. O dízimo no terceiro milênio. Visão Ecumênica. São Paulo: Edições Loyola. 1997

Manual essencial do dízimo. Instrumento, ferramenta e orientação para iniciação, compreensão e prática do dízimo na paróquia. São Paulo: Edições Loyola. 2017

SULCA, José L. Verdi, ARIZA, Newell Abiud Fonseca. Uma lei, duas tradições e muitos interesses. O código Deuteronômico e o projeto Sadoquista legislam sobre o dízimo. In CARNEIRO, Marcelo da Silva, OTTERMANN, Monika, FIGUEIREDO, Telmo José de Amaral (Org.) Pentateuco. Da formação à recepção: Contribuições ao VII Congresso ABIB UMESP. São Paulo. Paulinas. 2016. 